\title{
Increased expression of the calcium-activated chloride channel hCLCA1 in airways of patients with obstructive chronic bronchitis
}

\author{
Hans-Peter Hauber MD ${ }^{1}$, Celine Bergeron MD MSc ${ }^{1}$, Anne Tsicopoulos MD², Benoit Wallaert MD², \\ Ron Olivenstein $\mathrm{MD}^{1}$, Kenneth J Holroyd $\mathrm{MD}^{3}$, Roy $\mathrm{C}$ Levitt $\mathrm{MD}^{3}$, Qutayba Hamid MD PhD ${ }^{1}$
}

\begin{abstract}
H-P Hauber, C Bergeron, A Tsicopoulos, et al. Increased expression of the calcium-activated chloride channel hCLCA1 in airways of patients with obstructive chronic bronchitis. Can Respir J 2005;12(3):143-146.
\end{abstract}

BACKGROUND: Interleukin (IL)-9 and its effect on enhancing the human calcium-activated chloride channel 1 (hCLCA1) expression have been shown to induce mucin production. Increased expression of hCLCA1 may, in turn, contribute to mucus overproduction in chronic obstructive pulmonary disease (COPD) with a chronic bronchitis (CB) phenotype.

OBJECTIVE: To determine the expression of IL-9, IL-9 receptor (IL-9R), hCLCA1 and mucoglycoconjugates in COPD.

METHODS: Bronchial biopsies were obtained from six patients with obstructive CB and six healthy control subjects. IL-9, IL-9R and hCLCA1 expression were detected using immunohistochemistry. Additionally, in situ hybridization was performed to determine the expression of hCLCA1 messenger RNA. Mucin production was assessed using periodic acid-Schiff staining.

RESULTS: There was a significantly higher number of IL-9 immunoreactive cells in the submucosa of patients with COPD than that of healthy control subjects $(\mathrm{P}<0.05)$. Also, a significant increase in the expression of IL-9R, hCLCA1 (protein and messenger RNA) and mucin (periodic acid-Schiff-positive cells) was noted in the bronchial epithelium of patients with COPD compared the control subjects $(\mathrm{P}<0.05)$.

CONCLUSION: Increased expression of IL-9, IL-9R and hCLCA1 in the bronchial mucosa of patients with obstructive $\mathrm{CB}$ suggests that mucus overproduction in this disease may be, at least in part, due to hCLCA1.

Key Words: Chronic bronchitis; COPD; hCLCA1; Interleukin-9; Mucus

\section{Expression accrue du canal du chlorure activé par le calcium hCLCA1 dans les voies respira- toires de patients atteints de bronchite obstructive chronique}

HISTORIQUE : L'interleukine (IL)-9 et son effet stimulant sur l'expression du canal du chlorure activé par le calcium (hCLCA1) humain induirait la production de mucine. L'expression accrue du hCLCA1 peut, en retour, contribuer à la surproduction de mucus dans la maladie pulmonaire obstructive chronique (MPOC) avec phénotype de bronchite chronique (BC).

OBJECTIF : Déterminer l'expression de l'IL-9, du récepteur de l'IL-9 (IL-9R), du hCLCA1 et des mucoglycoconjugués dans la MPOC.

MÉTHODE : Des biopsies bronchiques ont été obtenues chez six patients souffrant de BC obstructive et chez six témoins en bonne santé. L'expression de l'IL-9, de l'IL-9R et du hCLCA1 a été mesurée par immunohistochimie. De plus, l'hybridation in situ a été utilisée afin de déterminer l'expression de l'ARN messager du hCLCA1. La production de mucine a été évaluée à l'aide de la réaction à l'acide périodique Schiff. RÉSULTATS : On a noté un nombre significativement plus élevé de cellules IL-9-immunoréactives dans la sous-muqueuse des patients atteints de MPOC que chez les sujets en bonne santé $(P<0,05)$. En outre, une augmentation significative de l'expression de l'IL-9R, du hCLCA1 (ARN protéique et messager) et de la mucine (cellules positives à la réaction à l'acide périodique Schiff) a été notée dans l'épithélium des bronches de patients atteints de MPOC, comparativement aux témoins $(\mathrm{P}<0,05)$.

CONCLUSION : L'expression accrue de l'IL-9, de l'IL-9R et du hCLCA1 dans la muqueuse bronchique des patients atteints de BC obstructive donne à penser que la surproduction de mucus typique de cette maladie pourrait en partie être due au hCLCA1.
$\mathrm{M}$

ucus overproduction is common in chronic obstructive pulmonary disease (COPD), particularly in patients with a chronic bronchitis phenotype (1). Excessive mucus production enhances airway obstruction, which suggests bacterial colonization and, consequently, pulmonary infection. However, the pathogenesis of mucus hypersecretion has not yet been fully elucidated. T helper cell 2 type cytokines, such as interleukin (IL)-4, IL-9 or IL-13, have recently been shown to upregulate the expression of the human calcium-activated chloride channel 1 (hCLCA1) (2,3). Introduction of hCLCA1 into the human mucoepidermoid cell line NCI-H292 induces mucin (MUC) gene expression and mucus production (4). Previous studies $(5,6)$ have also documented increased expression of hCLCA1 in the airways of patients with asthma or cystic fibrosis, further supporting the role of this channel in mucus hypersecretion. Because increased expression of IL-9, produced by CD3-positive $\mathrm{T}$ cells, has been described in the bronchial mucosa of patients with obstructive chronic bronchitis (7), we sought to investigate whether increased expression of hCLCA 1 is also a factor in this disease.

${ }^{1}$ Meakins-Christie Laboratories, McGill University, Montreal, Quebec; ${ }^{2}$ Institut Pasteur, Lille, France; ${ }^{3}$ Genaera Corporation, Plymouth Meeting, Pennsylvania, USA

Correspondence: Dr Qutayba Hamid, Meakins-Christie Laboratories, McGill University, 3626 St-Urbain Street, Montreal, Quebec H2X 2P2.

Telephone 514-398-3864, fax 514-398-7483, e-mail qutayba.hamid@mcgill.ca 


\section{METHODS}

\section{Subjects}

Six patients with COPD fulfilling the diagnosis criteria for chronic bronchitis with airway obstruction according to the American Thoracic Society guideline (8) (all men; mean age 62.5 years, ranging from 49 to 69 years) and six healthy, nonsmoking control subjects (five men, one woman; mean age 35.8 years, ranging from 19 to 51 years) were recruited. Patients with COPD were diagnosed with chronic bronchitis if they had a history of cough and sputum production on most days for a minimum of three months/year for the past two years. Fixed airway limitation was defined as a forced expiratory volume in $1 \mathrm{~s}$ less than $80 \%$ of predicted, with less than $15 \%$ improvement in forced expiratory volume in $1 \mathrm{~s}$ after inhalation of $400 \mu \mathrm{g}$ of salbutamol. All patients with COPD had a past history of cigarette smoking. All subjects were nonatopic (determined by skin prick testing) and had no clinical histories of allergy. Exclusion criteria included the presence of other lung diseases, systemic disease affecting the lungs, oral or inhaled corticosteroid use, exacerbations in the 12 weeks preceding the study and respiratory tract infections in the six weeks before the study. Approval was obtained from McGill University's (Montreal, Quebec) and from Institut Pasteur's (Lille, France) ethics committes, and informed consent was obtained from all subjects before recruitment into the study.

\section{Tissue collection and preparation}

Endoscopic bronchial biopsies were taken from the subcarinae of the lower and middle lobes. Three to four biopsies were obtained from all subjects. Biopsy specimens were either blocked in optimal cutting temperature medium by snap freezing in isopentanecooled liquid nitrogen for immunocytochemistry or blocked in $4 \%$ paraformaldehyde for in situ hybridization.

\section{Immunohistochemistry}

Bronchial sections were stained with periodic acid-Schiff (PAS) to identify mucus glycoconjugates. To detect IL-9, IL-9 receptor (IL-9R) and hCLCA1 expression, immunostaining was performed using the alkaline phosphatase-antialkaline phosphatase technique previously described (9). Specific antihuman antibodies against IL-9 (anti-IL-9, R\&D Systems, USA), IL-9R (anti-IL-9R, Santa Cruz Biotechnology, USA) and hCLCA1 (anti-hCLCA1, provided by Genaera Corporation, USA) were used. Negative isotype control studies were performed to confirm the specificity of the signal.

\section{In situ hybridization}

In situ hybridization with a radiolabelled complementary RNA probe was used to detect hCLCA1 messenger RNA (mRNA) in bronchial epithelium, as previously described $(10,11)$. In brief, complementary DNA was inserted into an expression vector, linearized and transcribed in vitro in both directions (antisense and sense probes) in the presence of $\mathrm{S}^{35}$-UTP, T7 and SP6 polymerase. After permeabilization, sections were prehybridized with $50 \%$ formamide in $2 \times$ standard sodium citrate for $15 \mathrm{~min}$ at $37^{\circ} \mathrm{C}$. Hybridization was carried out overnight at $40^{\circ} \mathrm{C}$ with a hybridization mixture containing hCLCA1, $\mathrm{S}^{35}$-labelled sense or antisense probe $\left(0.75 \times 10^{6} \mathrm{cpm} / \mathrm{slide}\right)$. Posthybridization involved a series of washes with decreasing concentrations of $2 \times$ standard sodium citrate at $42^{\circ} \mathrm{C}$. Samples were washed with ribonuclease solution for $20 \mathrm{~min}$ at $42^{\circ} \mathrm{C}$ to remove any unbound RNA probes. Hybridization signals were detected with standard autoradiography.

\section{Quantification}

All slides were read blinded (coded) and positive cells were counted. Epithelial cells with positive PAS staining, positive IL-9R cells and positive hCLCA1 cells were expressed as the percentage of positive cells per total number of epithelial cells. IL-9 immunoreactive cells were expressed as the number of positive cells per square millimetre of submucosa. Each slide was counted by two experienced observers. The intraobserver coefficient of variation for repeated measures was less than $5 \%$.

\section{Statistics}

The differences in the number of cells expressing IL-9, IL-9R, hCLCA1 proteins, hCLCA1 mRNA or staining positive for mucin (PAS) were compared using the nonparametric KruskalWallis test. Statistically significant differences between groups were subsequently analyzed with the Mann-Whitney U test (Systat version 7.0; SPSS Inc, USA). The results are expressed as mean \pm SEM, if not otherwise stated. $\mathrm{P}<0.05$ was considered statistically significant.

\section{RESULTS \\ Increased expression of hCLCA $1 \mathrm{mRNA}$ and protein in patients with COPD}

The percentage of cells expressing hCLCA1 mRNA and protein was significantly higher in the bronchial epithelium of patients with COPD $(64.6 \pm 9.4 \%$ and $54.2 \pm 12.4 \%$, respectively) than in samples from control subjects $(37.5 \pm 8.5 \%$ and $22.9 \pm 9.4 \%$, respectively; $\mathrm{P}<0.05$ ) (Figures 1 and 2 ).

\section{Increased expression of IL-9, IL-9R and PAS staining in patients with COPD}

The number of IL-9 immunoreactive cells was significantly higher in the submucosa of patients with COPD than in the submucosa of control subjects $\left(14.1 \pm 4.9\right.$ cells $/ \mathrm{mm}^{2}$ versus $7.0 \pm 2.6$ cells $/ \mathrm{mm}^{2}$, respectively; $\left.\mathrm{P}<0.05\right)$. Similarly, the percentage of cells expressing IL-9R in the bronchial epithelium of patients with COPD was significantly higher than in the bronchial epithelium of control subjects $(41.7 \pm 11.0 \%$ versus $17.5 \pm 3.1 \%$, respectively; $\mathrm{P}<0.05)$. Also, a significantly higher number of PAS-positive cells were observed in the bronchial epithelium of patients with COPD than in the bronchial epithelium of control subjects $(52.1 \pm 5.9 \%$ versus $20.8 \pm 10.0 \%$, respectively; $\mathrm{P}<0.05$ ) (Figure 2 ).

\section{DISCUSSION}

In the present study, we found an increased expression of IL-9 in the airways of patients with obstructive chronic bronchitis, which is in agreement with previous data (7). Furthermore, the expression of IL-9R, hCLCA1 and mucin protein (PAS staining) were elevated in the bronchial epithelium of patients with obstructive chronic bronchitis (COPD). These data correlate with previous findings which found similar increases in the airways of patients with asthma or cystic fibrosis $(5,6)$.

IL-9 has been reported to be produced by T cells in the submucosa of patients with chronic bronchitis (7). Furthermore, IL-9 is able to induce hCLCA1 and mucin protein expression in human primary lung cells $(2,3)$. There was a strong correlation between the protein expression of hCLCA1 and the IL-9R $(r=0.74)$, suggesting induction of hCLCA1 via the IL-9R. However, the correlation between hCLCA1 protein expression 

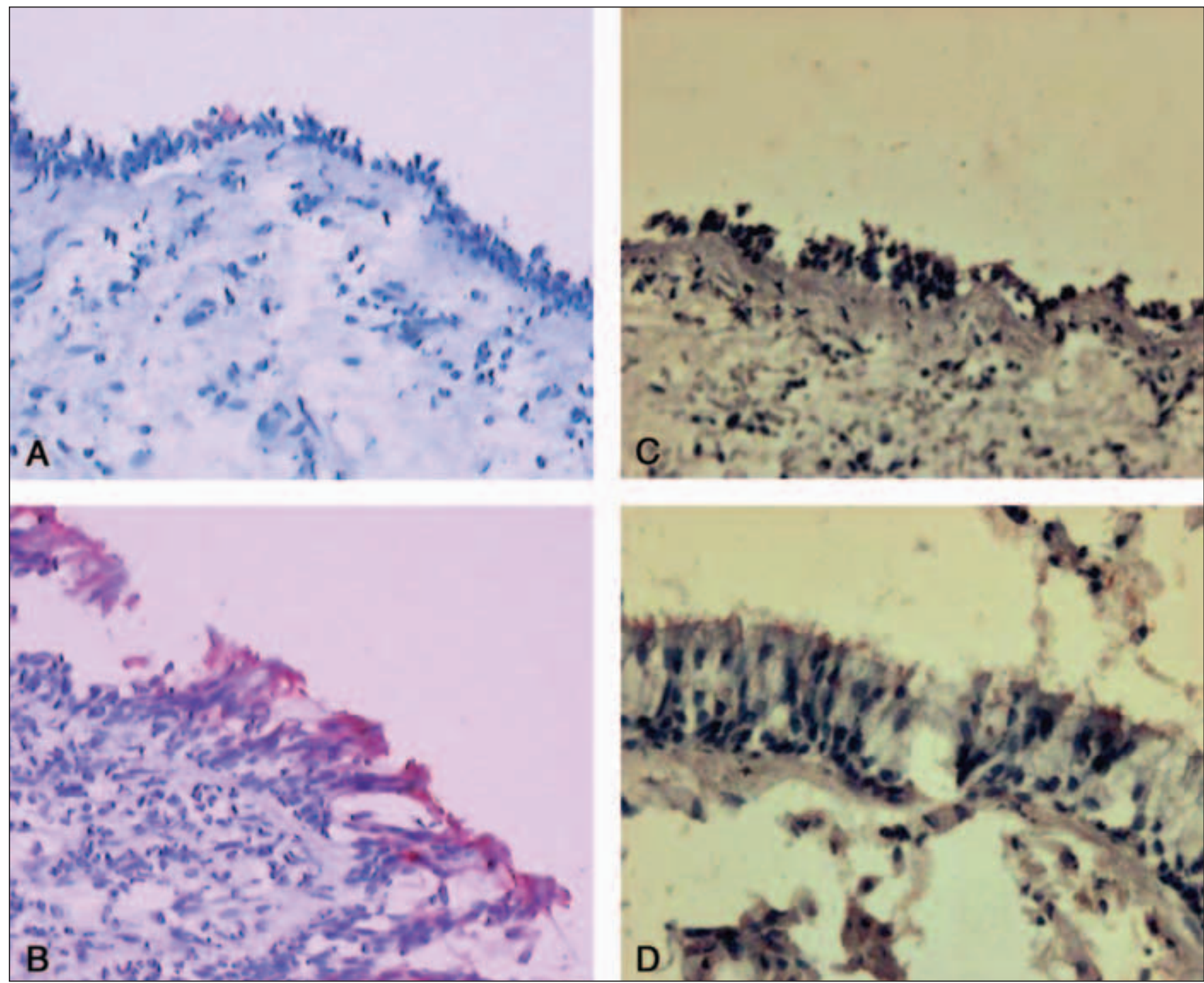

Figure 1) Representative example of immunohistochemistry for human calcium-activated chloride channel 1 in (A) the bronchial mucosa of a control subject and (B) a patient with chronic obstructive pulmonary disease with chronic bronchitis. $\mathbf{C}$ and $\mathbf{D}$ are representative examples of negative isotype control in a control subject and a patient with chronic obstructive pulmonary disease, respectively. Positive epithelial cells stain red. Original magnification $\times 400$

and PAS staining was weaker $(\mathrm{r}=0.54)$. This is not surprising because other mediators such as neutrophil elastase and lipopolysaccharide from Gram-negative bacteria have also been implicated in mucin production $(12,13)$.

The subjects in the control group in the current study were significantly younger than the patients with chronic bronchitis. Although we cannot exclude an age confounder, we do not believe that aging, by itself, can trigger an inflammatory and pathological profile as that observed in smoking-induced chronic bronchitis. In addition, it was also difficult to have an age-matched control group.

\section{CONCLUSION}

Our results suggest that mucus hypersecretion in the chronic bronchitis type of COPD may be due to increased expression of hCLCA1, triggered by IL-9.

FUNDING: This study was supported by Canadian Institutes of Health Research and Genaera Corporation (Plymouth Meeting, USA).

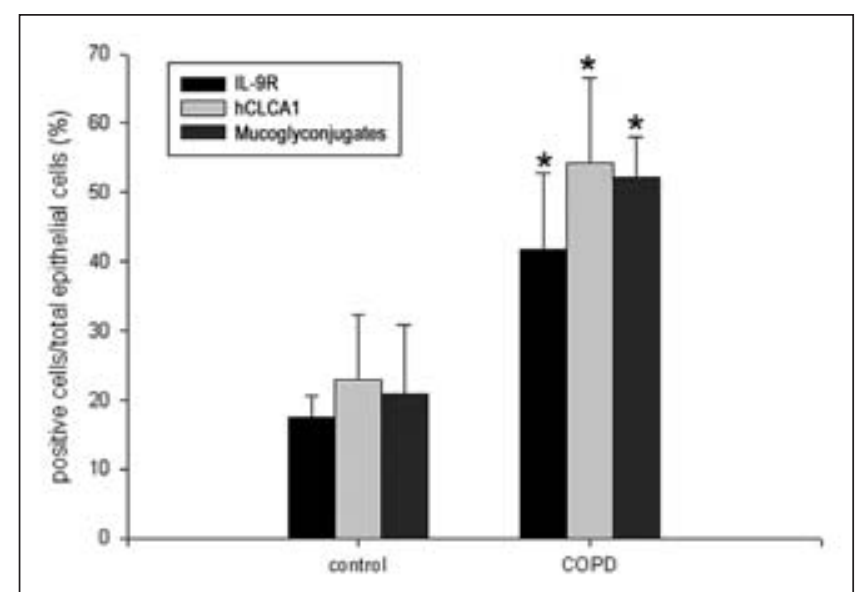

Figure 2) Expression of human calcium-activated chloride channel 1 (hCLCA1), interleukin-9 receptor (IL-9R) and mucoglyconjugates (periodic acid-Schiff staining) in the bronchial epithelium of control subjects and patients with chronic obstructive pulmonary disease (COPD). Mean values \pm SEM. $* P<0.05$ versus control subjects 


\section{REFERENCES}

1. Senior RM, Shapiro SD. Chronic obstructive pulmonary disease: Epidemiology, pathophysiology, and pathogenesis. In: Fishman AP, ed. Fishman's Pulmonary Diseases and Disorders. McGraw-Hill, New York, 1998;659-81.

2. Louahed J, Toda M, Jen J, et al. Interleukin-9 upregulates mucus expression in the airways. Am J Respir Cell Mol Biol 2000;22:649-56.

3. Zhou Y, Dong Q, Louahed J, et al. Characterization of a calciumactivated chloride channel as a shared target of Th2 cytokine pathways and its potential involvement in asthma. Am J Respir Cell Mol Biol 2001;25:486-91.

4. Nakanishi A, Morita S, Iwashita H, et al. Role of gob-5 in mucus overproduction and airway hyperresponsiveness in asthma. Proc Natl Acad Sci USA 2001;98:5175-80.

5. Toda M, Tulic MK, Levitt RC, Hamid Q. A calcium-activated chloride channel (HCLCA1) is strongly related to IL-9 expression and mucus production in bronchial epithelium of patients with asthma. J Allergy Clin Immunol 2002;109:246-50.

6. Hauber HP, Manoukian JJ, Nguyen LH, et al. Increased expression of interleukin-9, interleukin-9 receptor, and the calcium-activated chloride channel hCLCA1 in the upper airways of patients with cystic fibrosis. Laryngoscope 2003; 113:1037-42.

7. Panzner P, Lafitte JJ, Tsicopoulos A, Hamid Q, Tulic MK. Marked up-regulation of $\mathrm{T}$ lymphocytes and expression of interleukin-9 in bronchial biopsies from patients with chronic bronchitis with obstruction. Chest 2003;124:1909-15.

8. Standards for the diagnosis and care of patients with chronic obstructive pulmonary disease (COPD) and asthma. This official statement of the American Thoracic Society was adopted by the ATS Board of Directors, November 1986. Am Rev Respir Dis 1987;136:225-44.

9. Giaid A, Michel RP, Stewart DJ, Sheppard M, Corrin B, Hamid Q. Expression of endothelin-1 in lungs of patients with cryptogenic fibrosing alveolitis. Lancet 1993;341:1550-4.

10. Hamid Q, Azzawi M, Ying S, et al. Expression of mRNA for interleukin-5 in mucosal bronchial biopsies from asthma. J Clin Invest 1991;87:1541-6.

11. Hamid Q, Wharton J, Terenghi G, et al. Localization of atrial natriuretic peptide mRNA and immunoreactivity in the rat heart and human atrial appendage. Proc Natl Acad Sci USA 1987;84:6760-4.

12. Kim KC, Wasano K, Niles RM, Schuster JE, Stone PJ, Brody JS. Human neutrophil elastase releases cell surface mucins from primary cultures of hamster tracheal epithelial cells. Proc Natl Acad Sci USA 1987;84:9304-8.

13. Li JD, Dohrman AF, Gallup M, et al. Transcriptional activation of mucin by Pseudomonas aeruginosa lipopolysaccharide in the pathogenesis of cystic fibrosis lung disease. Proc Natl Acad Sci USA 1997;94:967-72. 


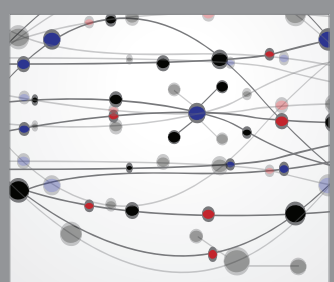

The Scientific World Journal
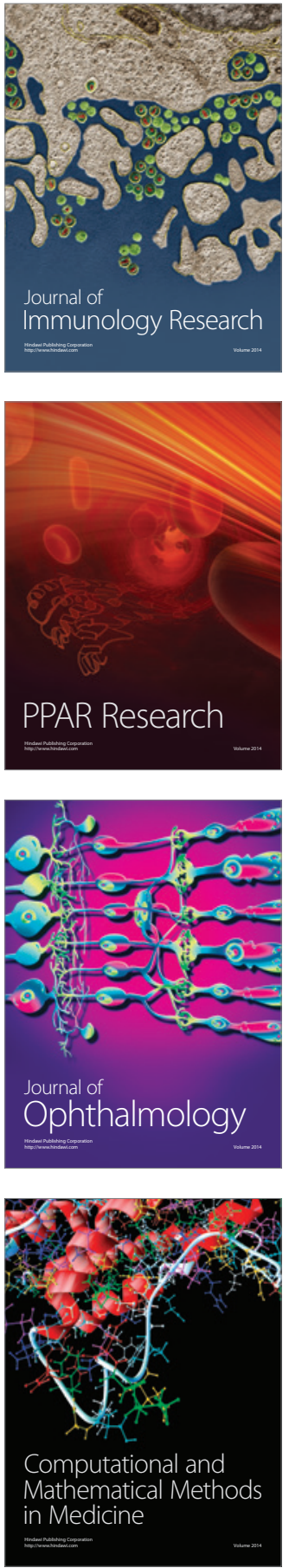

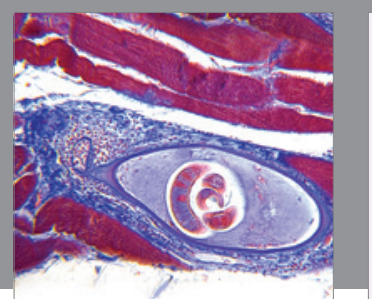

Gastroenterology Research and Practice

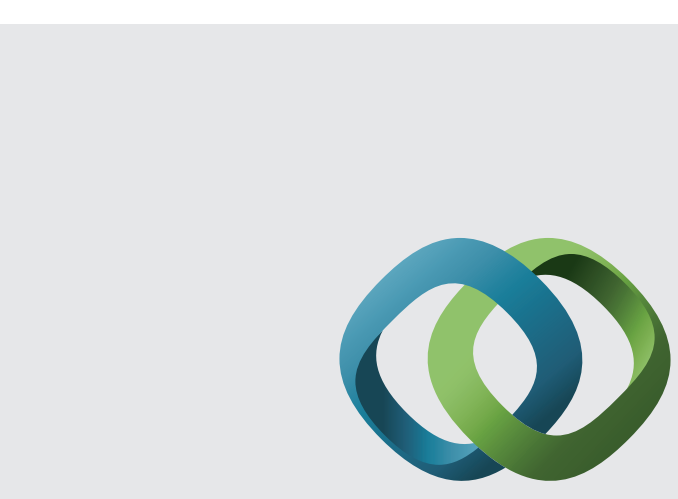

\section{Hindawi}

Submit your manuscripts at

http://www.hindawi.com
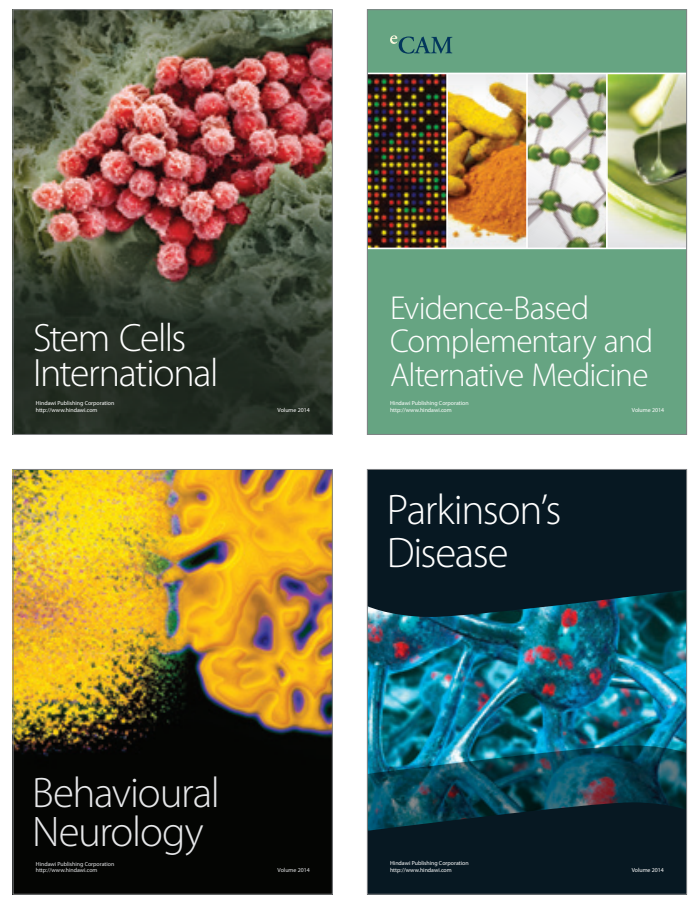
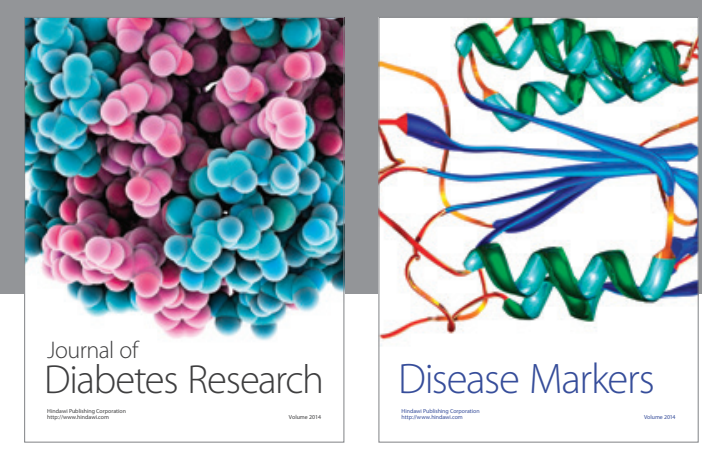

Disease Markers
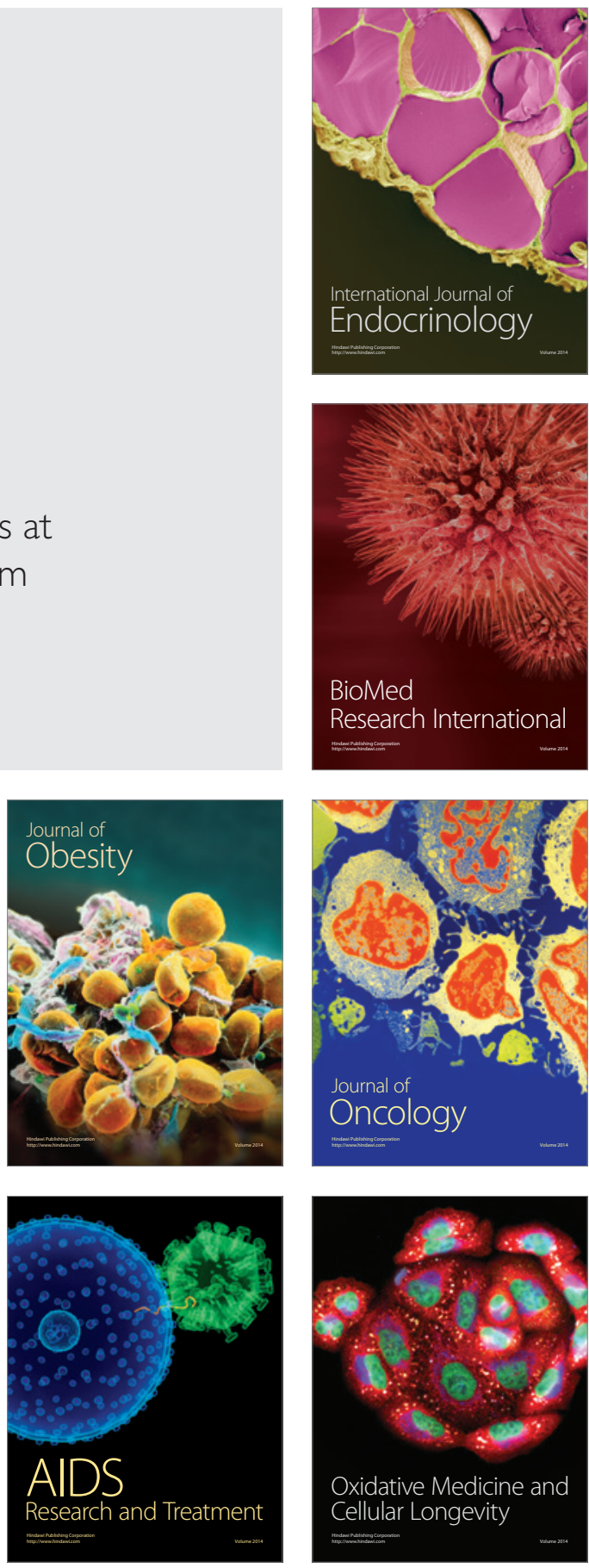